\title{
Design and Fabrication of a Three - Rolls Plate Bending Machine
}

\author{
Patrick Ejebheare Amiolemhen* Joseph Konas Abiegbe \\ Department of Production Engineering, Faculty of Engineering, University of Benin, \\ P.M.B 1154, Benin City, Nigeria
}

\begin{abstract}
This paper is aimed at designing and fabricating a low cost motorized 3-rolls plate bending machine to bend a metal plate up to $6 \mathrm{~mm}$ thick mild steel plates. The major components of the machine design for are: the rolls shaft diameters; thee chain drive; the spur gears drive and holding keys and the framework. Materials were selected to meet the machine requirements of strength, machine accuracy and reliability. The machine components were constructed by the various machining processes of cutting, turning and milling, and were thereafter arranged and joined together by appropriate joining methods such as welding and screw joints. The fabricated motorized 3-rolls plate bending machine with a $10 \mathrm{hp}$ electric motor is quite effective and efficient with maximum thickness of $6 \mathrm{~mm}$ mild steel plate. The total cost of production is $\$ 1,363.64$ which is relatively cheap compared to equivalent available in the market.
\end{abstract}

Keywords: Bending parameters, chain drive, keys, roll-bending, roll- shaft, spur gears drive.

DOI: $10.7176 /$ ISDE/10-6-05

Publication date:July $31^{\text {st }} 2019$

\section{Introduction}

In metalworking, rolling is a metal forming process in which a metal plate is passed through a pair or more rolls. Rolling is a complex process which is determined by the properties of the material being rolled; its thickness being a major factor. The parameters used in designing and fabricating the 3-rolls plate bending machine depends on these properties and the corresponding thickness of the material in use. In this process, the diameter of the metal plate or sheet being rolled does not change after the rolling. That is to say, that the initial and final thickness will be equal. The presence of cracks is also avoided during the course of the process. This was shown in the plastic and elastic deformation process in later stages (Boljanovic, 2004).

For the plastic deformation, the plate is expected to be able to retain its thickness after roll bending. Considering the magnitude of stresses that exist during the roll bending process of steel, as well as non-reduction in the thickness of the material, the roll bending process can be analyzed in two ways:

i. Bending in the centrally located inner zone, on both sides of the neutral zone, is a domain of elasticplastic deformation, while

ii. Bending in the outlying zones (on both the inside and outside of the bend), is a domain of pure plastic deformation.

Bending in the actual sense, is a domain of elastic-plastic deformation and can be considered as a linear stress problem (Carden et al., 2002).

In the rolling process, the radius through which the sheet steel is bent must be smaller than the required radius because of the spring back formation (Ahmed et al., 2012). They also show that the amount of spring back depends on several materials and such machine properties as the elasticity modulus, shape of the stress-strain curve, sheet thickness, roller dimensions, and so on. To study the spring back phenomenon produced on steel sheets, the rolling process is often used.

Yang and Shima (1988) discussed the distribution of curvature and calculated bending moment in accordance with the displacement and rotation of rolls by simulating the deformation of a workpiece with a U-shaped crosssection in a three-roller bending process.

Kim et al (2007) proposed a formulation to determine the bending force on rollers, the driving torque, and the power in the three-roll bending of a thin plate.

Analytical solutions of bending process have been presented by several researchers (Kim et al., 2007; Dongjuan et al., 2007; Wagoner and Li, 2007); however, for inverse analysis of springback in free bending process, a state of plain strain and negligible shear deformation is assumed (Behrouzi et al., 2008).

Asghari et al (2008), determined the force and power required to drive the three-roller plate bending machine, when it is unloaded with a workpiece and when it is load to roll a maximum of $5 \mathrm{~mm}$ steel plate.

Adsul et al (2013) stated that the factors that should be considered while calculating bending force are material properties, width, thickness, number of passes, bending radius, force developing mechanism and link.

The aim of this study is to design and fabricate a motorized 3-rolls plate bending machine to bend a metal plate up to $6 \mathrm{~mm}$ in thickness and $1200 \mathrm{~mm}$ in width into cylindrical forms. 


\section{Methodology}

\subsection{Design considerations}

For the machine to be reliable and accurate in its performance, there are so many factors to be considered. Some of the important design considerations are: properties of the metal plate to be rolled; size of the shaft (in diameter and length); the force, torque and power required to roll a given thickness and maximum reliable thickness.

\subsection{Design of machine elements}

\subsubsection{Design of Roll Shaft Diameter}

The force on acting on the sheet metal plate when the weight of the shaft is neglected and the shaft diameter were computed as $4064.6 \mathrm{~N}$ and $94.3 \mathrm{~mm}$, respectively using eqns. (1) and (2) given as (Olunlade et al., 2018):

$$
\begin{aligned}
& \mathrm{F}=\frac{4 \times \mathrm{E} \times \mathrm{I} \times \mathrm{Sf}}{\mathrm{R} \times \mathrm{L}_{\mathrm{sh}}} \\
& \mathrm{T}_{\mathrm{e}}=\sqrt{\mathrm{M}_{\mathrm{s} 2}+\mathrm{T}_{\mathrm{s} 2}}=\sqrt{6909820^{2}+2032.3 \mathrm{~d}_{\mathrm{s}}^{2}}=\frac{\pi}{16} \tau_{\text {as }} \cdot \mathrm{d}_{\mathrm{s}}^{3}
\end{aligned}
$$

Where,

$\mathrm{E}=$ modulus of elasticity of the sheet metal plate $=210 \times 10^{3} \mathrm{~N} / \mathrm{mm}^{2}$

$\mathrm{R}=$ radius of curvature $=\left(\mathrm{d}_{\max }+\mathrm{t}\right) / 2=1203 \mathrm{~mm}$

$\mathrm{d}_{\max }=$ maximum diameters of sheet metal to be rolled $=2400 \mathrm{~mm}$

$\mathrm{t}=$ maximum thickness of sheet metals to be rolled $=6 \mathrm{~mm}$

$\mathrm{I}=$ moment of inertia of sheet metal plate $=\mathrm{wh}^{3} / 12=21,945.6 \mathrm{~mm}^{4}$

$\mathrm{w}=$ width of mild steel sheet $=1219.2 \mathrm{~mm}$

$\mathrm{h}=$ thickness of mild steel sheet to be rolled $=6 \mathrm{~mm}$

$\mathrm{Sf}=$ factor of safety $=2$.

$\mathrm{L}_{\text {sh }}=$ length of rolling shaft $=1700 \mathrm{~mm}$

$\mathrm{M}_{\mathrm{s}}=$ banding moment $=\mathrm{F} \cdot \mathrm{L}_{\mathrm{sh}}=6909820 \mathrm{Nmm}$

$\mathrm{T}_{\mathrm{s}}=\mathrm{Fd}_{\mathrm{s}} / 2=2032 \mathrm{~d}_{\mathrm{s}} \mathrm{Nmm}$

$\mathrm{d}_{\mathrm{s}}=$ roll shaft diameter (to be determined)

$\tau_{\mathrm{as}}=$ allowable stress of the shaft interval $=42 \mathrm{~N} / \mathrm{mm}^{2}$.

And resolving the eqn. (4) Using standardized polynomial function and inserting values, the shaft diameter was computed as, $\mathrm{d}_{\mathrm{s}}=94.3 \mathrm{~mm}$. We use $\mathrm{d}_{\mathrm{s}}=100 \mathrm{~mm}$

2.2.2 Design of Drive Electric Motor Power

The bending moment of the cylindrical section $\mathrm{M}_{\mathrm{cs}}$, the bend angle $\theta$, the supporting force $\mathrm{F}_{2}$ on the roll plate and the pressure force $F_{1}$ generated by the upper roller (shown in Figure 1), the deformation torque $T_{d}$, the friction torque $\mathrm{T}_{\mathrm{f}}$, the roller drive torque $\mathrm{T}_{\mathrm{rd}}$ on the lower roller as well as the lower roller drive power $\mathrm{P}$ were computed as $3.38 \mathrm{KNm}, 20.69^{\circ}, 95.7 \mathrm{KN}, 179.1 \mathrm{KN}, 1.69 \mathrm{KNm}, 3.89 \mathrm{KNm}, 5.58 \mathrm{KNm}$ and $9.92 \mathrm{Hp}$, respectively from eqns. (3 - 10) given as (Boljanovic, 2004; www.machinemfg.com/08-02-2019):

$\mathrm{M}_{\mathrm{cs}}=\mathrm{k}_{\mathrm{r}} \cdot \mathrm{YS} \cdot \frac{\mathrm{W} \cdot \mathrm{t}^{2}}{4}$

$\theta=\sin ^{-1}\left(\frac{\alpha}{d_{\min }+d_{2}}\right)$

$\mathrm{F}_{2}=\frac{2 \mathrm{M}_{\mathrm{cs}}}{\mathrm{d}_{\min } \sin \theta}$

$\mathrm{F}_{1}=2 \mathrm{~F}_{2} \cos \theta$

$\mathrm{T}_{\mathrm{d}}=\frac{\mathrm{M}_{\mathrm{cs}} \mathrm{d}_{2}}{\mathrm{~d}_{\min }}$

$T_{\mathrm{f}}=\mathrm{f}\left(\mathrm{F}_{1}+2 \mathrm{~F}_{2}\right)+\mu\left(\mathrm{F}_{1} \frac{\mathrm{D}_{1}}{2} \frac{\mathrm{d}_{1}}{\mathrm{~d}_{2}}+\mathrm{F}_{2} \mathrm{D}_{2}\right)$

$\mathrm{T}_{\mathrm{rd}}=\mathrm{T}_{\mathrm{d}}+\mathrm{T}_{\mathrm{f}}$

$\mathrm{P}=\frac{2 \pi \mathrm{T}_{\mathrm{rd}} \mathrm{n}}{60 \eta}$

Where, 
$\mathrm{W}=$ maximum with of sheet place $=102192 \mathrm{~m}$

$\mathrm{t}=$ thickness of rolled stall sheet $=0.006 \mathrm{~m}$

$\mathrm{YS}=$ material Yield limit $=280 \times 10^{3} \mathrm{KN} / \mathrm{m}^{3}$

$\mathrm{k}_{\mathrm{r}}=$ reinforcement coefficient $=1.1$

$\alpha=$ lower roller centre distance $=\mathrm{d}_{\mathrm{s}}+\mathrm{t}=0.106 \mathrm{~m}$

$\mathrm{d}_{1}=\mathrm{d}_{2}=\mathrm{d}_{\mathrm{s}}=$ lower roller diameter $=0.10 \mathrm{~m}$

$\mathrm{d}_{\min }=$ minimum diameter of plate to be rolled $=2 \mathrm{~d}_{1}=0.20 \mathrm{~m}$

$\mathrm{d}_{2}=$ lower roller diameter $=0.10 \mathrm{~m}$

$\mathrm{f}=$ coefficient of rolling friction $=0.008$

$\mu=$ coefficient of sliding friction $=0.01$

$\mathrm{D}_{1}, \mathrm{D}_{2}=$ upper roller and lower roller diameter neck $=0.05 \mathrm{~m}$

$\mathrm{n}=$ lower roller rotational speed $=10 \mathrm{rpm}$

$\eta=$ transmission efficiency $=0.79$.

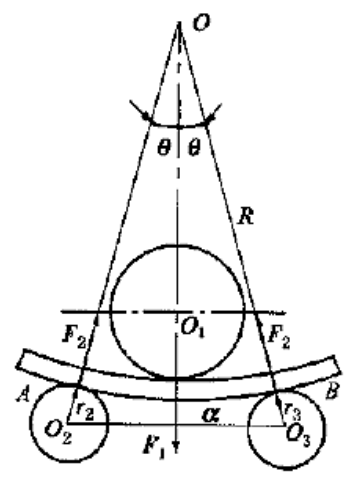

Figure 1: Force analysis of roll bending (www.machinemfg.com/08-02-2019)

\subsubsection{Bending Parameters}

The minimum bend radius, the maximum bend radius, the bend radius, bend allowance and the springback effect were computed as $0.018 \mathrm{~m}, 2.035 \mathrm{~m}, 1.20 \mathrm{~m}, 0.434 \mathrm{~m}$ and $0.21 \mathrm{~mm}$ respectively from eqns. (11 - 15) given as (Boljanovic, 2004):

$$
\begin{aligned}
& \mathrm{R}_{\mathrm{i}, \text { min }}=\mathrm{c.t} \\
& \mathrm{R}_{\mathrm{i}, \max }=\frac{\mathrm{t} \cdot \mathrm{E}_{\mathrm{s}}}{2 \mathrm{YS}} \\
& \mathrm{R}_{1}=\frac{\mathrm{d}_{\text {max }}}{2} \\
& \mathrm{~L}_{\mathrm{n}}=\frac{\pi \theta^{0}}{180^{0}} \sqrt{\mathrm{R}_{0} \mathrm{R}_{\mathrm{i}}} \\
& \mathrm{AR}=\left(\mathrm{R}_{1, \text { min }}+\frac{\mathrm{I}}{2}\right)\left(1-\mathrm{K}_{\mathrm{s}}\right)
\end{aligned}
$$

Where,

$\mathrm{c}=$ variety of materials $=3$

$\mathrm{t}=$ thickness of sheet mate plate $=0.06 \mathrm{~m}$

$\mathrm{E}_{\mathrm{s}}=$ modulus of elasticity of sheet plate material $=190 \times 10^{6} \mathrm{KN} / \mathrm{m}^{2}$

$\mathrm{YS}=$ yield stress of sheet plate material $=280 \times 10^{3} \mathrm{KN} / \mathrm{m}^{2}$

$\mathrm{d}_{\max }=$ diameter of roll sheet plate $=2.40 \mathrm{~m}$

$\theta=$ bend angle $=20.69^{0}$;

$\mathrm{R}_{0}=$ outer bend radius $=1.206 \mathrm{~m}$

$\mathrm{R}_{\mathrm{i}}=$ inner bend radius $=1.20 \mathrm{~m}$.

$\mathrm{R}_{\mathrm{i} \text {,min }}=$ Minimum bend radius $=18 \mathrm{~min}$

$\mathrm{K}_{\mathrm{s}}=$ Sheet metal plate factor $=0.99\left(\mathrm{R}_{\mathrm{f}} / \mathrm{t}=3\right.$ for plain carbon steel plate).

2.2.4 Design of Chain Drive

The chain drive design power, the member of teeth in the drive and driven sprockets, the triplex roller chain pitch, the chain speed, the torque transmitted by chain drive, the total pull on the chain drive, the bearing pressure of the chain drive, the permissible bearing pressure, the working factor of safety, the actual chain length, the pitch circle 
diameters of the chain drive, the outer diameters of the smaller and larger sprockets were computed were computed as $11.19 \mathrm{kw}, 17$ and $34,38.1 \mathrm{~mm}, 0.30 \mathrm{~m} / \mathrm{s}, 2544.21 \mathrm{Nm}, 24,930.3 \mathrm{~N}, 1510.9 \mathrm{~N} / \mathrm{cm}^{2}, 1820.3 \mathrm{~N} / \mathrm{cm}^{2} ; 17.05,69.78$ links $(2667 \mathrm{~mm}), 207.3 \mathrm{~mm}$ and $412.9 \mathrm{~mm}, 227.6 \mathrm{~mm}$ and $433.2 \mathrm{~mm}$, respectively from eqns. (16 - 28) given as (Iwis, 2010; Khurmi and Gupta, 2012):

$$
\begin{aligned}
& \mathrm{P}_{\text {des }}=\mathrm{k}_{\mathrm{c}} \times \mathrm{P}_{m} \\
& \mathrm{Z}_{\mathrm{c} 2}=\frac{\mathrm{n}_{\mathrm{c} 1}}{\mathrm{n}_{\mathrm{c} 2} \cdot \mathrm{Z}_{\mathrm{c} 1}} \\
& \mathrm{~V}_{\mathrm{c}}=\frac{\mathrm{Z}_{\mathrm{c} 1} \times \mathrm{n}_{\mathrm{c} 1} \times \mathrm{p}}{60,000} \\
& \mathrm{M}_{\mathrm{c}}=\frac{9550 \times \mathrm{P}_{\mathrm{m}}}{\mathrm{n}_{\mathrm{c} 1}} \\
& \mathrm{p}_{\mathrm{T}}=\mathrm{p}_{\mathrm{t}}+\mathrm{p}_{\mathrm{c}}+\mathrm{p}_{\mathrm{s}} \\
& \mathrm{P}_{\mathrm{r}}=\frac{\mathrm{P}_{\mathrm{T}}}{\mathrm{A}_{\mathrm{r}}} \\
& \mathrm{P}_{\mathrm{P}}=\frac{\mathrm{P}_{\mathrm{v}} \cdot \lambda}{\mathrm{f}_{1} \cdot \mathrm{f}_{2}} \\
& \text { Working factor of safety }=\frac{\text { breaking load }}{\text { design load }} \geq 7.0 \\
& \mathrm{~L}_{\mathrm{c}}=2 \mathrm{a}_{\mathrm{p}}+\frac{\mathrm{Z}_{\mathrm{c} 1}+\mathrm{Z}_{\mathrm{c} 2}}{2}+\frac{\left(\mathrm{Z}_{\mathrm{c} 2}-\mathrm{Z}_{\mathrm{c} 1}\right)}{39.5 \mathrm{a}_{\mathrm{p}}} \\
& \mathrm{d}_{01}=\frac{\mathrm{p}}{\sin \left(\frac{180^{0}}{\mathrm{Z}_{\mathrm{c} 1}}\right)} \\
& \mathrm{d}_{2}=\frac{\mathrm{p}}{\sin \left(\frac{180^{0}}{\mathrm{Z}_{\mathrm{c} 2}}\right)}
\end{aligned}
$$

Where,

$\mathrm{K}_{\mathrm{c}}=$ load concentration factor $=\mathrm{k}_{1} \times \mathrm{k}_{2} \times \mathrm{k}_{3}$

$\mathrm{k}_{1}=$ heavy shape coefficient $=1.4$

$\mathrm{k}_{2}=$ fabrication coefficient $=0$

$\mathrm{k}_{3}=$ tooth factor $=1.25$

$\mathrm{P}_{\mathrm{m}}=$ motor power $=10 \mathrm{hp}=7.46 \mathrm{~kW}$.

$\mathrm{Z}_{\mathrm{cl}}=$ number of teeth in the driver sprocket (taking as min teeth) $=17$

$Z_{\mathrm{c} 2}=$ number of teeth in the driven sprocket $=34$.

$\mathrm{n}_{\mathrm{c} 1}=$ motor speed $=28 \mathrm{rpm}$

$\mathrm{n}_{\mathrm{c} 2}=$ driven shaft speed $=14 \mathrm{pm}$

$\mathrm{P}_{\mathrm{t}}=24,866.7 \mathrm{~N}$

$\mathrm{P}_{\mathrm{c}}=1.8 \mathrm{~N}$

$\mathrm{P}_{\mathrm{s}}=61.8 \mathrm{~N}$

$\mathrm{P}_{\mathrm{T}}=$ total pull on drain $=24,930.3 \mathrm{~N}$

$\mathrm{A}_{\mathrm{r}}=$ bearing are $=16.50 \mathrm{~cm}^{2}$

$\mathrm{P}_{\mathrm{v}}=$ bearing pressure for corresponding teeth $=2912.5 \mathrm{~N} / \mathrm{cm}^{2}$

$\lambda=$ friction travel $=0.63$

$\mathrm{f}_{1}=$ effect of lubrication $=1.0$ 
$\mathrm{f}_{2}=$ for drive comprising two shafts $=100 \mathrm{~cm}$

Breaking load $=425000 \mathrm{~N}$

Design load $=$ total pull on drain $=24,930.3 \mathrm{~N}$

$\mathrm{a}_{\mathrm{p}}=$ Centre distance, $\mathrm{C} /$ pitch, $\mathrm{p}=1000 / 38.1=26.25 \mathrm{~mm}$

$\mathrm{p}=$ chain pitch $=38.1 \mathrm{~mm}$

$\mathrm{d}_{1}=$ outer diameters of the smaller sprocket $=207.3 \mathrm{~mm}$

$\mathrm{d}_{2}=$ outer diameters of the larger sprocket $=412.9 \mathrm{~mm}$

$\mathrm{d}_{\mathrm{o}}=$ roller diameter $=25.4 \mathrm{~mm}$

2.2.5 Design of spur gear drive

The transmission ratio of the spur gear, the minimum number of teeth on the pinion to avoid interference, the gear life in number of cycles, the initial design torque, the equivalent young modulus of elasticity of the pinion and wheel, the design bending stress on gears teeth rotating in both directions, the design compressive (contact) stress on gears teeth, the minimum centre distance between the pinion and wheel, the number of teeth in the pinion and wheel of the gear drive, the module of the gear, the revised centre distance, the revised design torque of pinion, the bending strength of gear, the wear strength were computed as $1.4,14,0.84 \times 10^{7}$ cycles, $6614.93 \mathrm{Nm}, 206 \mathrm{x}$ $10^{3} \mathrm{~N} / \mathrm{mm}^{2}, 361.84 \mathrm{MPa}, 1364.07 \mathrm{MPa}, 230 \mathrm{~mm}, 20$ and 28 teeth, $240 \mathrm{~mm}, 72 \mathrm{~mm}, 200 \mathrm{~mm}$ and $280 \mathrm{~mm}, 0.15 \mathrm{~m} / \mathrm{s}$, $0.36,5603223.51 \mathrm{Nmm}, 196.78 \mathrm{MP}_{\mathrm{a}}, 1232.33 \mathrm{MPa}$, respectively from eqns. $(29-47)$ given as (Chand et al., 2012):

$$
\begin{aligned}
& \mathrm{i}=\frac{\mathrm{n}_{\mathrm{g} 1}}{\mathrm{n}_{\mathrm{g} 2}} \\
& z_{\text {min }}=\frac{2 \mathrm{~A}_{\mathrm{w}}}{\mathrm{i}\left[\sqrt{\left.1+\frac{1}{\mathrm{i}}\left(\frac{1}{\mathrm{i}}+2\right) \sin ^{2} \varphi-1\right]}\right.} \\
& \mathrm{g}_{1}=60 \times \mathrm{x}_{1} \times \mathrm{x}_{2} \times \mathrm{x}_{3} \times \mathrm{x}_{4} \times \mathrm{n}_{\mathrm{g} 1} \\
& {\left[\mathrm{M}_{\mathrm{t}}\right]=\mathrm{k}_{\mathrm{g}} \cdot \mathrm{M}_{t}} \\
& \mathrm{E}_{\mathrm{eq}}=\frac{2 \mathrm{E}_{\mathrm{g} 1} \times \mathrm{E}_{\mathrm{g} 2}}{\mathrm{E}_{\mathrm{g} 1}+\mathrm{E}_{\mathrm{g} 2}} \\
& {\left[\sigma_{\mathrm{b}}\right]=\frac{\sigma_{\mathrm{e}}}{\mathrm{k}_{\mathrm{e}} \text { fos }}} \\
& {\left[\sigma_{\mathrm{c}}\right]=\mathrm{C}_{\mathrm{R}} \times \mathrm{H}_{\mathrm{RC}} \times \mathrm{K}_{\mathrm{cl}}} \\
& \mathrm{a} \geq(\mathrm{i}+1) \sqrt[3]{\left(\frac{0.74}{\left[\sigma_{\mathrm{c}}\right]}\right) \times \frac{\mathrm{E}_{\mathrm{eq}} \times\left[\mathrm{M}_{\mathrm{t}}\right]}{\mathrm{i} \times \psi}} \\
& \mathrm{Z}_{\mathrm{g} 2}=\mathrm{i} \times \mathrm{Z}_{\mathrm{g} 1} \\
& \mathrm{~m}=\frac{2 \times \mathrm{a}}{\mathrm{Z}_{g 1}+\mathrm{Z}_{g 2}} \\
& \mathrm{a}_{\mathrm{r}}=\frac{\mathrm{m}\left(\mathrm{Z}_{\mathrm{g} 1}+\mathrm{Z}_{\mathrm{g} 2}\right)}{2} \\
& \mathrm{~b}=\psi \mathrm{xa} \\
& \mathrm{d}_{\mathrm{g} 1}=\mathrm{m} \times \mathrm{Z}_{\mathrm{g} 1} \\
& \mathrm{~d}_{\mathrm{g} 2}=\mathrm{m} \times \mathrm{Z}_{\mathrm{g} 2} \\
& \mathrm{~V}_{\mathrm{g}}=\frac{\pi \times \mathrm{d}_{\mathrm{g} 1} \times \mathrm{n}_{\mathrm{g} 1}}{60} \\
& \psi_{\mathrm{p}}=\frac{\mathrm{b}}{\mathrm{d}_{\mathrm{g} 1}} \\
& {\left[\mathrm{M}_{\mathrm{t}}\right]_{r}=\mathrm{M}_{\mathrm{t} .} \mathrm{k}_{\mathrm{c}} \mathrm{k}_{\mathrm{d}}} \\
& \sigma_{\mathrm{b}}=\frac{(\mathrm{i}+1) \times\left[\mathrm{M}_{\mathrm{t}}\right]_{r}}{\mathrm{a} \times \mathrm{m} \times \mathrm{b} \times \mathrm{y}}
\end{aligned}
$$




$$
\sigma_{\mathrm{c}}=0.74 \times\left(\frac{\mathrm{i}+1}{\mathrm{a}}\right) \sqrt{\left(\frac{\mathrm{i}+1}{\mathrm{i} \times \mathrm{b}}\right) \times \mathrm{E}_{\mathrm{eq}} \times\left[\mathrm{M}_{\mathrm{t}}\right]_{\mathrm{r}}}
$$

Where,

$\mathrm{n}_{\mathrm{g} 1}=$ speed of pinion gear $=14 \mathrm{rpm}$

$\mathrm{n}_{\mathrm{g} 2}=$ speed of wheel $=10 \mathrm{rpm}$

$\mathrm{A}_{\mathrm{w}}=$ fraction by which standard addendum for the wheel should be multiplied $=1$

$\mathrm{i}=$ transmission ratio $=1.4$

$\varphi=$ pressure angle $=20^{\circ}$

$\mathrm{x}_{1}=$ number of runs per day $=8$ hours

$\mathrm{x}_{2}=$ number of days runs per week $=6$ days

$\mathrm{x}_{3}=$ number of weeks runs per gear $=52$ weeks

$\mathrm{x}_{4}=$ number of years runs $=14 \mathrm{rpm}$

$\mathrm{K}_{\mathrm{g}}=$ Design load factor $=1.3$

$\mathrm{M}_{\mathrm{t}}=$ transmitted power $=7.460 \mathrm{~kW}$

$\mathrm{E}_{\mathrm{g} 1}=\mathrm{E}_{\mathrm{g} 2}=$ Young's modulus of electricity of pinion and wheel $=206 \times 10^{3} \mathrm{~N} / \mathrm{mm}^{2}$

$\sigma_{\mathrm{e}}=$ Fatigue strength $=1 / 2 \sigma_{\mathrm{u}}=825 \mathrm{MPa}$

$\sigma_{\mathrm{u}}=$ ultimate stress of AISI 4340 steel

$\mathrm{K}_{\mathrm{e}}=$ Fatigue strength reduction factor $=1.2$

fos $=$ factor of safety $=1.9$

$\mathrm{C}_{\mathrm{R}}=26.5 ; \mathrm{H}_{\mathrm{RC}}=50$; for $\mathrm{HB} \geq 350$

$\mathrm{N}=0.84 \times 10^{7}<25 \times 10^{7}$ cycles

$\mathrm{K}_{\mathrm{cl}}=6 \sqrt{\frac{10^{7}}{\mathrm{~N}}}=1.03$

$\psi=$ initial gear form $=0.30$.

$\mathrm{K}_{\mathrm{c}}=$ load concentration factor $=1.01$

$\mathrm{K}_{\mathrm{d}}=$ dynamic load factor $=1.1$

$\mathrm{y}=$ form factor $=0.384$.

2.2.6 Design of keys for pinion/wheel

The diameter of the round key to secure the pinion and wheel to the roll shaft was computed as $27.71 \mathrm{~mm}$ from eqn. (48) given as (Bhandari, 2012):

$$
\mathrm{d}_{\mathrm{pm}}=\frac{2 \mathrm{M}_{\mathrm{t}}}{1 \times \tau_{\mathrm{cpin}} \times \mathrm{d}_{\mathrm{s}, \mathrm{pin}}}
$$

Where,

$\mathrm{M}_{\mathrm{t}}=$ torque transmitted $=5088410 \mathrm{Nmm}$

$1=$ length of pin $=72 \mathrm{~mm}$

$\tau_{\mathrm{c}, \text { pin }}=$ allowable shear stress $=85 \mathrm{~N} / \mathrm{mm}^{2}$

$\mathrm{d}_{\mathrm{s}, \mathrm{pin}}=$ shaft diameter $=60 \mathrm{~mm}$.

\subsection{Assembly and mounting of machine components}

The various stages of assembly and mounting of the machine components are shown in plates 1-4. 


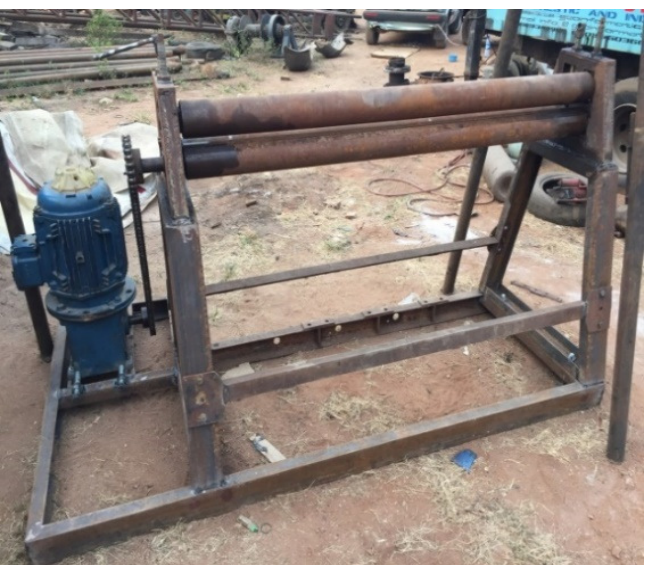

Plate 1: Back view of the three roller bending machine

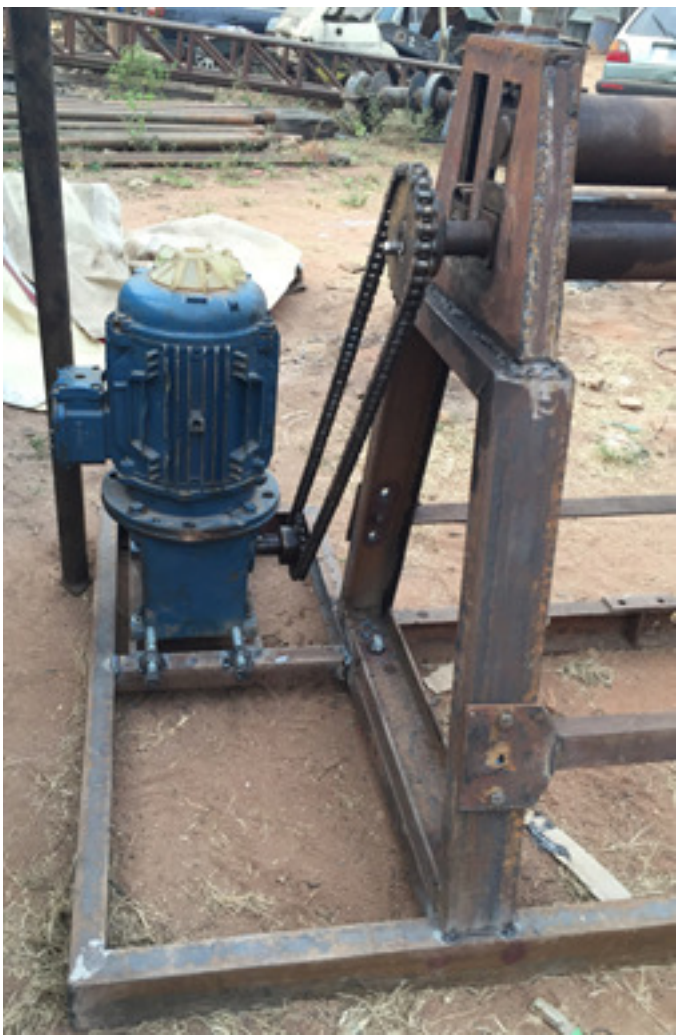

Plate 3: Picture showing the electric motor and jacking bolts for chain adjustment

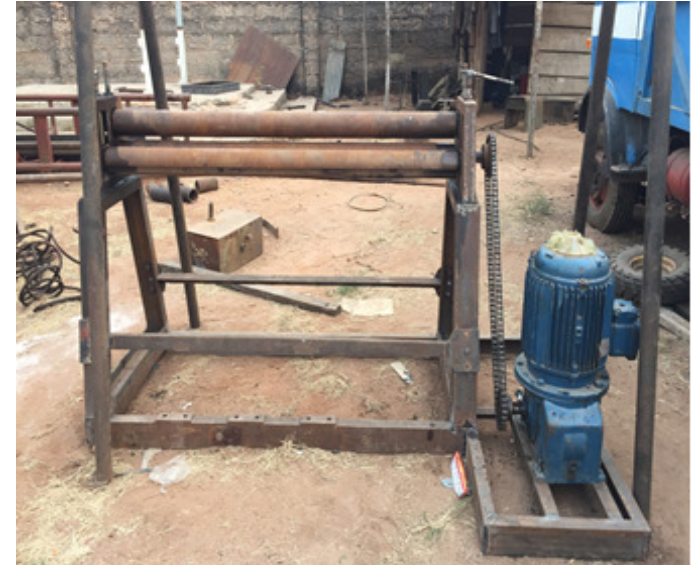

Plate 2: Front view of the three roller bending machine

\subsection{Machine Description}

The motorized three-roller plate bending machine consists of six main parts: the frame; the 3- rolls; shafts; the roll screws, the control panel; the speed control system (consisting of gears, chain drive and control panel) and the electric motor. The electric motor drives the driver gear that controls the main roll which is connected to the driven roll thus taking the sheet of metal to be rolled. The frame was also constructed with ultimate stability and cares to avoid fracture or breakage owing to the weight of the rollers, the electric motor, the gear system and other peripheral components. This was done to ensure maximum safety for the user.

\subsection{Working principle:}

According to the principle of the three-point forming circle, the relative position change and rotational motion of the working roll make the metal sheet produce continuous plastic deformation to obtain the predetermined shape of the work piece. Three rolls bending machine usually take two lower rollers as active roll, can realize positive 
and reverse rotation. One upper roller is a follower roll, can move vertically up and down. When rolling steel plate is placed between the upper and lower rollers, and the three cutting points that are exposed to the metal sheet by three rolls can make the plate behind into a curved closed circle. Therefore, the forming process of sheet metal can be regarded as the three- roll bending machine to make a continuous three-point bending process. During processing, one end of the metal plate is feed into three-roller plate between the upper and lower roller, and then top roller bring downward displacement on the metal plate, which make the plate under it generate a certain plastic bending deformation due to compression. When the roller is rotating, there is friction between the plate and toll, so when the roll is rotated, the plate also moves along its longitudinal direction. Lower roller under positive and negative rotation alternately and rolled plate move back and forth, two lower roller rotation and the friction drive plate and roller move meanwhile, the upper roller continue to add downward pressure on the roller, the upper roller moves back and forth on the plate. When the plate pass the bottom of upper roller (the roller deformation zone) in turn, and stress exceeds the yield limit, it will produce plate deformation, the plate obtained the plastics bending deformation along the full length, and processed into the required shape. Adjust the relative position between the upper and lower rolls properly, and the plate can be bent to a radius not less than the radius of the upper roller.

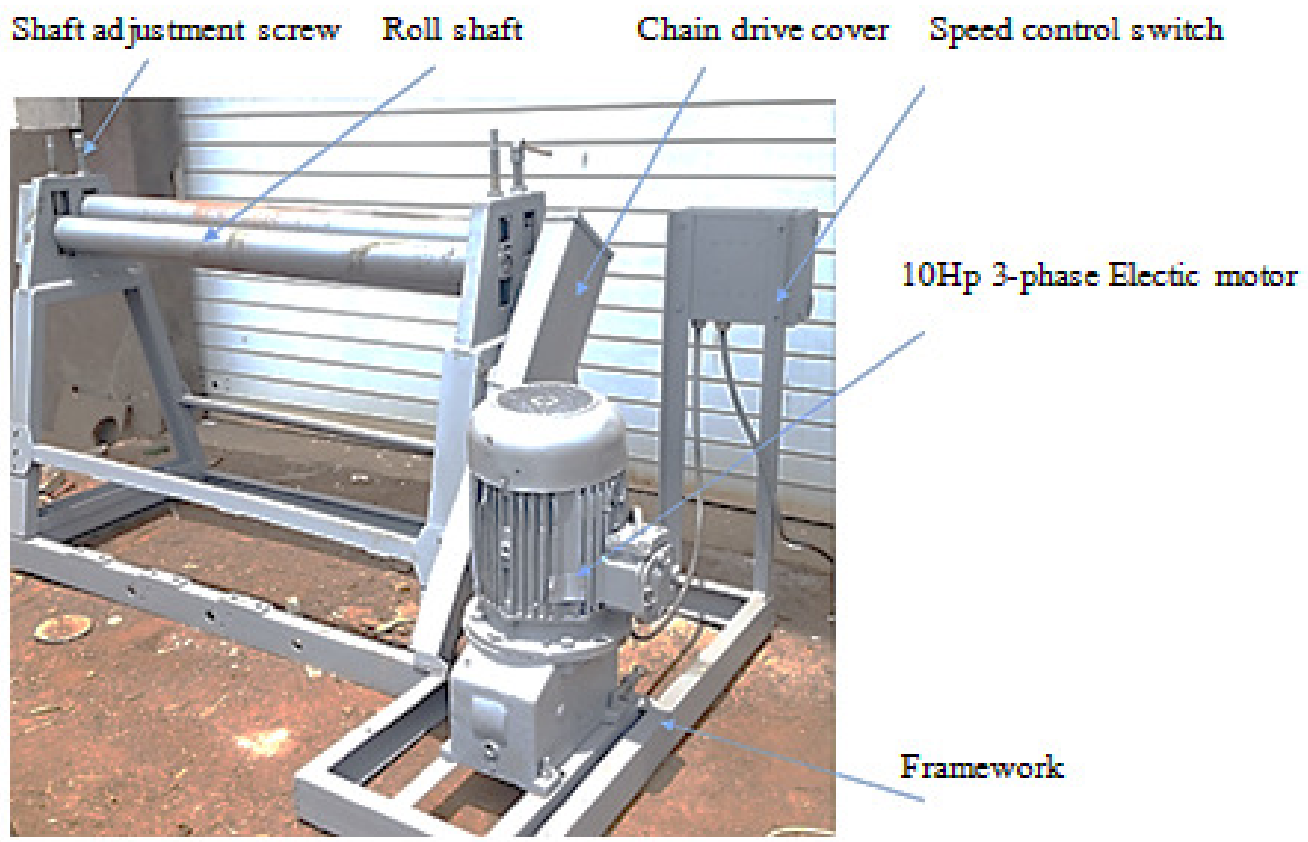

Plate 5: The 3-roller plate bending machine fabricated.

\section{Results and discussion}

\subsection{Results}

The summary of results of the machine components design is shown in Table 1. 
Table 1: Summary of results of machine components design

\begin{tabular}{|c|c|c|c|}
\hline $\mathbf{S} / \mathbf{N}$ & Machine components & Component description & Values \\
\hline \multirow[t]{7}{*}{1} & Sheet metal plate & Maximum thickness of plate & $6 \mathrm{~mm}$ \\
\hline & & Maximum width of plate & $1219.2 \mathrm{~mm}$ \\
\hline & & Maximum roll diameter & $2400 \mathrm{~mm}$ \\
\hline & & Bend allowance & $0.434 \mathrm{~m}$ \\
\hline & & Maximum bend radius & $2.035 \mathrm{~m}$ \\
\hline & & Minimum bend radius & $0.018 \mathrm{~m}$ \\
\hline & & Springback effect & $0.21 \mathrm{~mm}$ \\
\hline \multirow[t]{2}{*}{2} & Electric motor & 3-phase gear motor & $10 \mathrm{Hp}$ \\
\hline & & Motor speed & $28 \mathrm{rpm}$ \\
\hline \multirow[t]{11}{*}{3} & Chain drive & Centre distance & $1000 \mathrm{~mm}$ \\
\hline & & Transmission ratio & 2 \\
\hline & & Drive sprocket teeth & 34 \\
\hline & & Driven sprocket teeth & 17 \\
\hline & & Chain type & Triple \\
\hline & & Chain pitch & $38.1 \mathrm{~mm}$ \\
\hline & & Chain speed & $0.30 \mathrm{~m} / \mathrm{s}$ \\
\hline & & Pitch circle diameter of driver sprocket & $207.3 \mathrm{~mm}$ \\
\hline & & Outer diameter of driver sprocket & $227.6 \mathrm{~mm}$ \\
\hline & & Outer diameter of driven sprocket & $433.2 \mathrm{~mm}$ \\
\hline & & Chain length & 69.78 links or $667 \mathrm{~mm}$ \\
\hline \multirow[t]{18}{*}{4} & Spur gears & Transmission ratio & 1.4 \\
\hline & & Pinion teeth & 20 \\
\hline & & Wheel teeth $=28$ & 28 \\
\hline & & Minimum centre distance between pinion and wheel & 240 \\
\hline & & Speed of pinion gear & $14 \mathrm{rpm}$ \\
\hline & & Speed of wheel & 10rpm \\
\hline & & Pitch line velocity & $0.15 \mathrm{~m} / \mathrm{s}$ \\
\hline & & Module & $10 \mathrm{~mm}$ \\
\hline & & Face width & $72 \mathrm{~mm}$ \\
\hline & & Weight factor & 1 \\
\hline & & Bottom clearance & $25 \mathrm{~mm}$ \\
\hline & & Pitch circle diameters of pinion & $200 \mathrm{~mm}$ \\
\hline & & Pitch circle diameters of wheel & $280 \mathrm{~mm}$ \\
\hline & & Tooth depth & $22.5 \mathrm{~mm}$ \\
\hline & & Tip diameter of pinion, & $220 \mathrm{~mm}$ \\
\hline & & Tip diameter of wheel & $300 \mathrm{~mm}$ \\
\hline & & Root diameter of pinion & $175 \mathrm{~mm}$ \\
\hline & & Root diameter of wheel & $255 \mathrm{~mm}$ \\
\hline \multirow[t]{2}{*}{5} & Roll shafts & Shaft diameter & $100 \mathrm{~mm}$ \\
\hline & & Shaft speed & $10 \mathrm{rpm}$ \\
\hline \multirow[t]{2}{*}{6} & Keys & Length of pin & $72 \mathrm{~mm}$ \\
\hline & & Diameter of pin & $30 \mathrm{~mm}$ \\
\hline
\end{tabular}

\subsection{Discussion}

Table 1 shows the values of the machine components obtained from the design. Figure 2 shows the exploded view of the machine parts, while Figure 3 shows the orthographic views of the 3-rolls plate bending machines. Plates 14 show the various stages of the assembly and mounting of the machine components, while the assembled machine is shown in plate 5 .

\section{Conclusion}

The design and fabrication of a low cost motorized 3-rolls plate bending machine to bend a metal plate up to $6 \mathrm{~mm}$ thick mild steel plates has been carried. The major components of the machine designed were: the rolls shaft diameters; the chain drive; the spur gears drive and holding keys and the framework. Materials were selected to meet the machine requirements of strength, machine accuracy and reliability. The machine components were constructed by the various machining processes of cutting, turning and milling, and were thereafter arranged and joined together by appropriate joining methods such as welding and screw joints. The fabricated motorized 3-rolls plate bending machine with a $10 \mathrm{hp}$ electric motor is quite effective and efficient with maximum thickness of $6 \mathrm{~mm}$ 
mild steel plate. The total cost of production is $\$ 1,363.64$ which is relatively cheap compared to equivalent available in the market.

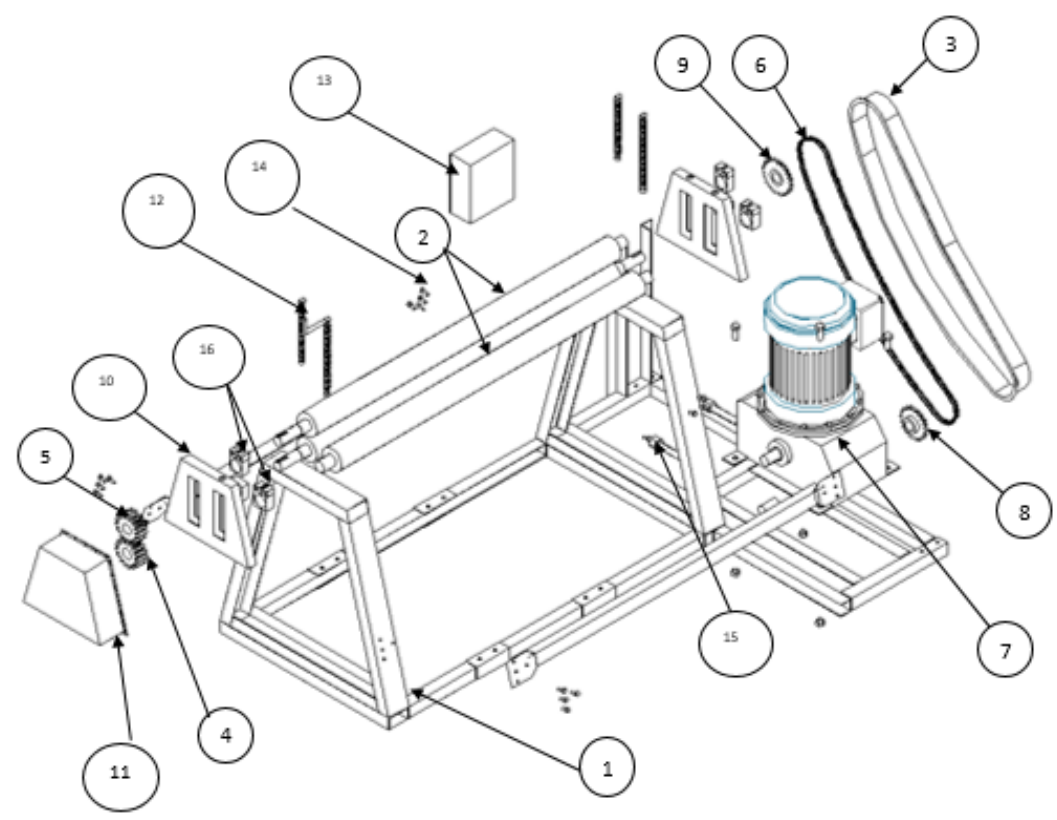

\begin{tabular}{|c|l|l|}
\hline \multicolumn{3}{|c|}{ PARTS LIST } \\
\hline Item\# & \multicolumn{1}{|c|}{ Item Description } & No. Off \\
\hline 1 & $\begin{array}{l}\text { Steel frame (U } \\
\text { channel 50x100) }\end{array}$ & \\
\hline 2 & Roller Shafts & \\
\hline 3 & Sprocket Chain Cover & \\
\hline 4 & Gear & \\
\hline 5 & Pinion & \\
\hline 6 & Chain & \\
\hline 7 & Electric Motor & \\
\hline 8 & Sprocket (Driver) & \\
\hline 9 & $\begin{array}{l}\text { Shaft Sprocket } \\
\text { (Driven) }\end{array}$ & \\
\hline 10 & Bushing & \\
\hline 11 & $\begin{array}{l}\text { Gear and Pinion } \\
\text { Cover }\end{array}$ & \\
\hline 12 & Screw & \\
\hline 13 & Switch Box & \\
\hline 14 & Hexagonal Bolt N Nut & \\
\hline 15 & Tensioning Bolt & \\
\hline 16 & Bushing & \\
\hline
\end{tabular}

Figure 2: Exploded view of the 3-rolls plate bending machine
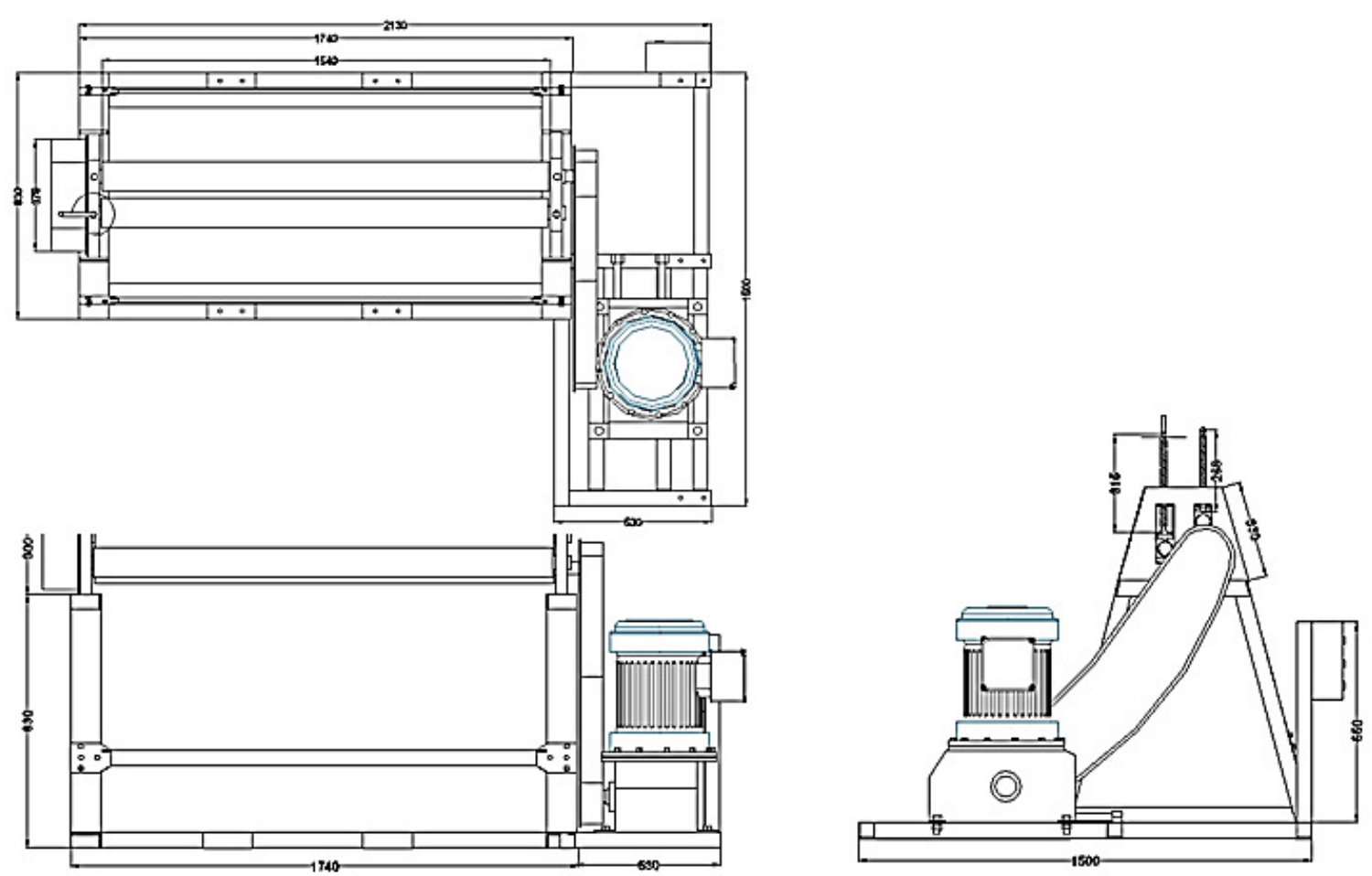

Figure 3: Orthographic projections of the 3-rolls plate bending machine

\section{References}

Adsul, A.N., Chavan, S.G., Gore, P.N. (2013). Review of theories regarding material bending. International Journal of Scientific and Engineering Research. Vol. 4. No. 10. Pp. $1293-1299$.

Ahmed, K., Zied, A., Nader, H., and Khaled, E. (2012). Modeling and Computation of the three- roller bending process of steel sheets. Journal of Mechanical Science and Technology, Tunis, 26(1), 123-128.

Asghari, A., Alimardani, R., Akram, A., \& Karparvar, H. (2008). Effect of auger speed and air Flow on discharge rate of bagasse. American -Eurasian Journal of Agricultural \& Environmental Science, 3(5), 743-747.

Behrouzi, M., Shakeri, B. and Mollaei, D. (2008). Inverse Analysis of Springback in Sheet Metal Forming by 
Finite Element Method. International Conference on Engineering Optimization.June1-5, 2008: Rio de Janeiro, Brazil.

Bhandari, V. B. (2012). Design of machine elements (3 ${ }^{\text {rd }}$ edition). The McGraw-Hill Companies, New Delhi, IndiaCarden, W. D., Geng, L. M., Matlock, D. K. and Wagnor, R.H. (2002). Measurement of springback. International Journal of Mechanical Sciences. 44, 79-101.

Boljanovic, V. (2004). Sheet metal forming processes and die design. Industrial press Inc., New York. 5, 64-87.

Chand, A.G., Sharma, A.V.N.L., Kumar, K.P., Sainath, K., Aravind, I. (2012). Design of spur gear and its tooth profile. International Journal of Engineering Research and Applications (IJERA). Vol.2. No.2.pp. 820 - 827.

Dongjuan, Z., Zhenshan C., Xueyu, R. and Yuqiang, L. (2007). An analytical model for predicting springback and side wall curl of sheet after U-bending. Computation Materials Sci. 38(2):707-715.

Iwis. (2010). Handbook for chain engineering. www.iwis.com / $07-02-2019$.

Khurmi, R. S. and Gupta, J. K. (2007). Machine Design. S.C. Chand Publishers. Pp. 10 - 1055.

Kim, H., Nargundkar, N. and Altan, T. (2007). Prediction of bend allowance and springback in air bending. ASMEJ. Manufacturing Sci. Eng. 129:342-351.

lunlade, B. A., Ogundola, J., Odiba, O. and Obaje, O. (2018). Development of a Motorized Sheet Metal Rolling Machine. Advances in Research. 17(1): 1-9.

Wagoner, R. H. and Li, M. (2007). Simulation of springback: through thickness integration. International Journal of Plasticity. 23(3). $345-360$.

Yang, S. M. and Shima, S. (1988). Simulation of pyramidal type three-roller bending process. International Journal of Mechanical Science. 30 - 12. 866 - 877.https://www.machinemfg.com/load-analysis-driven-powercalculation-symmetrical-3-roll-plate-bending machine/ $(08-02-2019)$. 